補綴誌, J Jpn Prosthodont Soc, $44: 160 \sim 167,2000$.

原著論文

\title{
食品捸取アンケートを用いた顎関節症患者の咀嚼機能評価
}

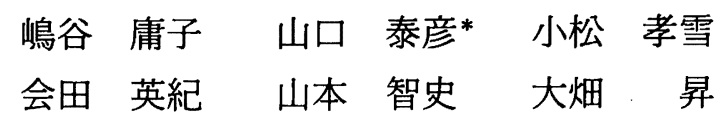

\section{Evaluation of Masticatory Function in Temporomandibular Disorder \\ Patients Using Questionnaire on Dietary Intake}

\author{
Youko Shimaya, Taihiko Yamaguchi*, Kousetsu Komatsu, \\ Hideki Aita, Satoshi Yamamoto and Noboru Ohata
}

\begin{abstract}
Questionnaires on dietary intake were given to 62 temporomandibular disorder (TMD) patients and 31 normal volunteers in order to evaluate masticatory function in TMD patients. The results were as follows :

1. For several of the foods listed in the questionnaire, a high percentage of the subjects gave answers that were not useful for data analysis such as "dislike," "don't eat" or "don't know." The results suggested that more thought must be given to probable likes and dislikes of the subjects regarding food when designing a questionnaire on dietary intake.

2. The score of chewing difficulty (SCD), obtained by matching the answers provided by the subjects with their chewing difficulties, was significantly higher in patients with pain than in normal volunteers. However, the distribution of SCD in TMD patients was very large and the SCD did not coincide with the presence of pain in some patients, suggesting that the degree of chewing difficulty differs greatly among TMD patients. This method of using SCD based on data obtained from questionnaires to evaluate masticatory function is thought to be useful for understanding exactly how the diet of TMD patients is affected by their symptoms.
\end{abstract}

Key words : masticatory function, temporomandibular disorders, questionnaire on dietary intake, score of chewing difficulty

I. 緒 言

顎関節症患者には, 咀嚼筋群や顎関節の痛みにより咀鲴 障害が認められることが多い。咀嚼障害については，一般 的に問診で簡単に調べられている程度であるが, Quality

北海道大学歯学部歯科補緅学第二講座（主任：大畑 昇教授)

• 北海道大学歯学部附属病院特殊歯科治療部

Department of Crown \& Bridge Prosthodontics, School of Den. tistry, Hokkaido University (Chief : Prof. Noboru Ohata)

*Department of Special Clinic for Specific Disorders, Dental Hospital, Hokkaido University

平成 11 年 4 月 5 日受付 of Life (QOL) が歯科治療においても重要視されてきて いる現在, 澦関節症の症状が患者の食生活へどのような影 響を及ほしているかを, より詳細に検討する必要があると 考えられる，過去において，顎関節症患者の咀嚼筋筋電 図 ${ }^{123)}$ や顎運動経路4)の診査結果から咀嚼機能を評価し, 頡関節症患者の咀嚼機能の低下について報告した研究はい くつかみられるものの, これらの検査機器による検査結果 からだけでは, 個々の患者の食生活の支障度を評価するの は難しいのが現状である。

食品摄取アンケートは, 従来, 主に総義歯など補緅物装 着患者の咀嚼機能評価に用いられており, 簡易でかつ患者 の食生活を的確に評価できる方法とされている ${ }^{5 \sim 14)}$. 栗田 
$ら^{15,16)}$ は, この方法を顎関節機能障害患者に応用し, 患者 の機能面の評価に有用であるとしている。しかし, 従来の アンケートに用いられた食品は総義歯装着者を対象として 選定された食品が中心であり，顎関節症患者の年齢層での 個々の食品の嗜好性に関する検討はほとんど行われていな いため, 顎関節症患者の多数が日常的に攝取しない食品も 含まれている可能性は高い. そこでわれわれは, 食品捸取 アンケートに用いる食品については，患者の好き嫌いが比 較的少なく日常的に摄取する食品であるか否かを考慮する 必要があると考え, はじめに食品別の嗜好性を分析し, 咀 噮機能の評価に用いる食品の選別を行った. さらに, 選定 した食品に関するアンケート結果を用いて, 顎関節症患者 の咀嚼機能について検討を行った.

\section{II. 研究方法}

\section{1. 被験者}

被験者は, 本学歯学部附属病院に来院した顎関節症患者 から無作為に選択したなかから下記の咬合条件の患者を除 いた 62 名（12 歳～50 歳, 平均 25.5 歳）および澦口腔系 に異常の認められない正常者 31 名（19 歳～50 歳, 平均 26.0 歳)とした。

表 1 Characteristics of the subjects 被験者の概要

\begin{tabular}{lrrcc}
\hline \hline & $\begin{array}{c}\text { 男性 } \\
\text { (人) }\end{array}$ & $\begin{array}{c}\text { 女性 } \\
\text { (人) }\end{array}$ & $\begin{array}{c}\text { 合計 } \\
\text { (人) }\end{array}$ & $\begin{array}{c}\text { 平均年齢 } \\
\text { (墄) }\end{array}$ \\
\hline 患者群 & 15 & 47 & 62 & 25.5 \\
・筋痛群 & 7 & 15 & 22 & 23.5 \\
•関節痛群 & 3 & 10 & 13 & 23.5 \\
・筋・関節痛群 & 0 & 13 & 13 & 31.4 \\
・無痛群 & 5 & 9 & 14 & 24.6 \\
正常者群 & 6 & 25 & 31 & 26.0 \\
\hline
\end{tabular}

患者群は, 症状別に筋痛群, 関節痛群, 筋・関節痛群, 無痛群に 4 分類した. 筋痛群は咀畄関連筋のみに疼痛を有 する患者, 関節痛群は顎関節のみに疼痛を有する患者, 筋・関節痛群は筋痛と顎関節痛の両方を有する患者で, そ れぞれ顎関節雑音の併発患者も含むことにした．無痛群は 雑音のみの患者および無痛性開口障害の患者とした. 義歯 装着者, 欠損歯列を有する者は対象から除いた（表 1). なお，各群間の年齢に関しては分散分析（ポストホックテ スト：Scheffe 法), 性別に関しては $\chi^{2}$ 独立性の検定にお いて危険率 $5 \%$ で有意な偏りは認められなかった。

\section{2. 食品㩑取アンケート}

食品摂取アンケートに用いた食品は, 総義歯患者の咀嚼 機能の評価に関する文献をもとに選んだ食品に，日常摂取 すると思われる食品を補足した 82 食品とした（表 2 ）.

アンケートの回答の選択肢および咀嚼障害の程度を表す スコアは，「普通に食べられる（スコア 0 点）」「工夫すれ

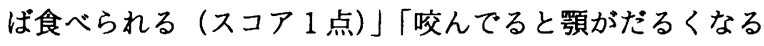
(スコア 2 点)」「咬むと痛くて食べられない（スコア 3 点)」「嫌い・食べない（スコアなし）」「わからない・知ら ない(スコアなし)」とし, 重複選択は不可とした.

\section{3. 咀哷困難スコアと食品スコアの算出}

各被験者におけるすべての食品のスコアの合計を「嫌 い・食べない」「わからない・知らない」以外の選択がな された食品数で除した值を個人の咀嚼困難スコア（score of chewing difficulty, 以下 SCD と記す) とし, 咀畄機 能の評価に用いた.

また，各食品におけるすべての被験者のスコアの合計を 被験者数で除した值を食品スコアとし, 咀嚼時に支障をき たしやすい食品の評価に用いた。

表 2 The 82 food items listed in the questionnaire 食品摂取アンケートに用いた 82 食品

\begin{tabular}{|c|c|c|c|c|}
\hline ・あさり（煮） & ・キャベツ（ゆで） & ・スパゲッティー & ・とんかつ & • 豚肉（焼） \\
\hline ・揚げ煎餅 & ・キャべツ（生） & ・するめ & ・梨 & ・フランスパン \\
\hline ・あられ & - 牛肉（煮） & ・ゼリー & ・なす（煮） & ・プリン \\
\hline ・あわび（煮） & ・きゅうり & ・セロリ & ・納豆 & •干しぶどう \\
\hline • いか刺し & ・グミ & ・雑煮もち & ・なまこ & ・ポッキー \\
\hline •うどん & ・クラゲ酢 & ・ソーセージ & •にんじん（生） & ・ポテトチップス \\
\hline ・うなぎ & ・ごほう（煮） & ・だいこん（煮） & -にんじん（ゆで） & ・まぐろ刺身 \\
\hline •枝豆 & ・こんにゃく & ・たくあん & ・練りようかん & ・マシュマロ \\
\hline ・海老天ぷら & ・こんふ（煮） & • 玉子焼き & • 白菜漬け & •みかんの袋 \\
\hline ・おかき & ・ご飯 & ・タマネギ（煮） & ・八ム & - 焼肉 \\
\hline ・おかゆ & • 魚（者） & ・チース & ・はんぺん & ・焼きもち \\
\hline ・おこし & ・さといも（煮） & ・ちくわ & ・ピーナッツ & ・らっきょう \\
\hline • 貝柱の干物 & ・しいたけ（煮） & ・とうふ & ・ビーフジャーキー & ・レタス \\
\hline ・カステラ & ・食パン（白い所） & ・トマト & ・ビーフステーキ & ・れんこん（著） \\
\hline ・かずのこ & ・食パン（みみ） & • 鷄肉（揚） & ・ピザ & \\
\hline ・かまほこ & ・スープ & • 鷄肉（煮） & ・Uじき & \\
\hline ・ガム & ・酢だこ & ・とり貝 & ・ビスケット & (50 音順) \\
\hline
\end{tabular}




\section{4. 食品摂取アンケートに適した食品の選定}

各食品の㖺好性を分析し, 食品摄取アンケートに適した 食品の選定を行うために以下の検討を行った。

全被験者を対象として，食品ごとに「嫌い・食べない」 「わからない・知らない」の回答肢を選んだ被験者の割合 (無効回答率) を算出した。さらに, 全食品, 無効回答率 $30 \%$ 未満の食品, 同 $20 \%$ 未満の食品, 同 $10 \%$ 未満の食
品, 同 $5 \%$ 末満の食品を選定した場合のそれぞれの条件で 患者群の SCD の平均值を算出し，その結果からアンケー トに用いる食品の選定を行った。

\section{5. 正常者と顎関節症患者の SCD の検討}

選定された食品に関するアンケート結果から，患者群と 正常者群の SCD の比較，また患者群の症状別 SCD の比

表 3 Percentage of invalid answers given for each food item 各食品における無効回答率

\begin{tabular}{|c|c|c|c|c|c|c|c|c|c|}
\hline & 本研究 & 細井ら ${ }^{8)}$ & 安斎ら & 榎本ら ${ }^{14}$ & & 本研究 & 細井ら ${ }^{8)}$ & 安斎ら" & 榎本ら ${ }^{14)}$ \\
\hline なまこ & 45 & - & 20 & 35 & 揚げ巔餅 & 5 & 2(堅焼き煎餅) & $\triangle$ & - \\
\hline とり貝 & 45 & - & - & - & ちくわ & 5 & 2 & $\triangle$ & 3 \\
\hline らっきょう & 38 & - & $\triangle$ & 5 & ハム & 5 & 2 & $\triangle$ & 7 \\
\hline クラゲ酢 & 30 & - & 17 & 23 & ピーフステーキ & 5 & 5 & $\triangle$ & 11 \\
\hline ピーフジャーキー & 26 & - & - & - & 牛肉（者） & 5 & - & $\Delta$ & - \\
\hline 干しぶどう & 25 & - & - & - & 誐肉（焼） & 5 & - & $\triangle$ & - \\
\hline あわび & 24 & - & $\triangle$ & - & 鶏肉（者） & 5 & - & $\triangle$ & 5 \\
\hline セロリ & 23 & - & 13 & - & とんかつ & 5 & - & $\Delta$ & 4 \\
\hline 練りようかん & 23 & - & - & 3 & ピーナッツ & 5 & 7 & $\triangle$ & 5 \\
\hline 酢だこ & 23 & 18 & $\triangle$ & 11 & 食パン（みみ） & 4 & - & - & - \\
\hline マシュマロ & 22 & - & - & - & カステラ & 4 & - & $\Delta$ & - \\
\hline グミ & 22 & - & - & - & にんじん（ゆで） & 4 & - & $\triangle$ & 1 \\
\hline おこし & 18 & 11 & $\triangle$ & 10 & きゅうり & 4 & - & $\triangle$ & 4 \\
\hline かずのこ & 17 & - & $\triangle$ & 4 & ソーセージ & 4 & - & $\triangle$ & 12 \\
\hline うなぎ & 17 & 9 & $\triangle$ & 11 & 鶏肉（揚） & 4 & - & $\triangle$ & 5 \\
\hline みかんの袋 & 16 & - & - & - & ポッキー & 4 & - & - & - \\
\hline あさり（煮） & 15 & - & $\triangle$ & 12 & ピザ & 3 & - & - & - \\
\hline 貝柱の干物 & 14 & - & - & - & ごほう（者） & 3 & - & $\triangle$ & 2 \\
\hline れんこん（煮） & 13 & - & - & 1 & レタス & 3 & - & - & 3 \\
\hline 白菜溑け & 13 & - & $\triangle$ & 0 & トマト & 3 & - & - & 4 \\
\hline するめ & 13 & 16 & $\triangle$ & 11 & 魚（煮） & 3 & 2 & $\triangle$ & 2 \\
\hline こんぶ（煮） & 13 & - & - & 3 & 枝豆 & 3 & - & $\triangle$ & 4 \\
\hline 雑煮もち & 12 & 0 & - & 4 & 玉子焼き & 3 & - & $\triangle$ & 2 \\
\hline さといも（諸） & 12 & - & $\triangle$ & 3 & ピスケット & 3 & - & $\triangle$ & - \\
\hline 納豆 & 12 & - & - & 5 & ポテトチップス & 3 & - & $\triangle$ & - \\
\hline にんじん（生） & 11 & - & $\triangle$ & 13 & プリン & 3 & - & $\triangle$ & 6 \\
\hline はんぺん & 11 & 2 & $\triangle$ & 8 & ゼリー & 3 & - & $\triangle$ & - \\
\hline あられ & 11 & - & $\triangle$ & 8 & おかゆ & 2 & 0 & $\triangle$ & 1 \\
\hline なす（煮） & 10 & - & $\triangle$ & 1 & キャベツ（なま） & 2 & - & $\triangle$ & 7 \\
\hline まぐろ刺身 & 10 & 0 & $\triangle$ & 4 & タマネギ（煮） & 2 & - & $\triangle$ & 3 \\
\hline たくあん & 9 & - & $\triangle$ & 6 & 焼肉 & 2 & - & - & - \\
\hline ひじき & 9 & - & - & 4 & 海老天ぷら & 2 & - & $\triangle$ & - \\
\hline チース & 9 & - & $\triangle$ & 10 & こんにゃく & 2 & 0 & $\triangle$ & 1 \\
\hline 焼きもち & 8 & - & - & - & ご飯 & 1 & 0 & $\triangle$ & 1 \\
\hline フランスパン & 8 & 9 & $\triangle$ & 13 & 食パン（白い所） & 1 & - & $\Delta$ & 2 \\
\hline おかき & 8 & - & - & - & だいこん（渚） & 1 & - & $\triangle$ & 3 \\
\hline いか刺し & 6 & 11 & $\Delta$ & 6 & 梨 & 1 & - & $\triangle$ & 4 \\
\hline かまぼこ & 6 & 0 & $\Delta$ & 3 & うどん & 0 & - & $\triangle$ & 3 \\
\hline しいたけ（煮） & 6 & - & $\triangle$ & 2 & スパゲッティー & 0 & - & - & - \\
\hline キャベツ（ゆで） & 5 & - & $\triangle$ & 2 & とうふ & 0 & 0 & $\Delta$ & 1 \\
\hline ガム & 5 & - & 一 & 一 & スープ & 0 & 一 & $\triangle$ & - \\
\hline \multicolumn{10}{|c|}{ 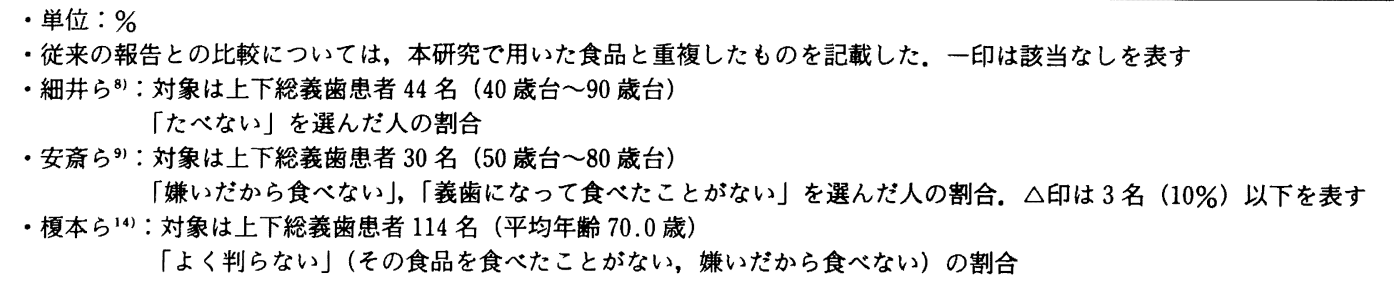 } \\
\hline
\end{tabular}


較を行った。

統計処理は, 分散分析およびポストホックテストとして Scheffe 法を用いて行い，5\%の危険率で有意差の検定を 行った.

\section{III. 結 果}

1. 食品摂取アンケートに用いる食品の選定について 表 3 に全食品の無効回答率を示す．無効回答率 $30 \%$ 末 満は 78 食品, 同 $20 \%$ 未満は 70 食品, 同 $10 \%$ 未満は 52 食品, 同 $5 \%$ 未満は 32 食品であった. 図 1 に全食品, 無 効回答率 $30 \%$ 末満の食品, 同 $20 \%$ 未満の食品, 同 $10 \%$ 末満の食品, 同 $5 \%$ 末満の食品を選定した条件での患者群 の SCD の平均値を示す. 全食品, 無効回答率 $30 \%$ 末満, $20 \%$ 末満， $10 \%$ 末満の各 SCD の值はそれぞれ，0.39， $0.39,0.37,0.35$ と近似していたが, 無効回答率 $5 \%$ 末 満の食品を除いた場合の 32 食品では, 0.24 と他の SCD より数值が急激に低下していた。これらの結果に基づき， 無効回答率 $10 \%$ を選定の基準とすることにした。すなわ ち, 無効回答率が $10 \%$ 以上の 30 食品を除いた 52 食品を 最終的にアンケートに用いることにした.

\section{2. 食品スコア}

選定された 52 食品での食品スコアは, 正常者群ではフ ランスパンが 0.13 で, 他の食品の食品スコアはいずれも 0であった。一方, 患者群における食品スコアでは, 高い ものとして, フランスパン, ガム, 食パン (みみ), 揚げ 煎餅, ビーフステーキ, たくあんが 0.8 以上, 焼きもち, いか刺し，とんかつ，おかき，ピーナッツ，豚肉（焼き）, ピザが $0.6 〜 0.8$ であった. 食品スコアが 0 の食品はなく, 比較的容易に捸取できそうなプリン，とうふ，スープなど でも何らかの数值を示していた（図2).

\section{3. 正常者群と患者群の SCD の分布}

正常者群の SCD の平均は $0.003 \pm 0.01$, 一方, 患者群 では $0.31 \pm 0.36$ と大きな差が認められた. SCDの分布に 関しては, 正常者群では，31名中 29 名 (94\%) で SCD が 0, 2 名 (6\%) が 0.02 0.1で, 患者群で, 62 名中 15 名 (24\%) が SCD が0で, 11 名（17\%）が 0.02〜0.1で 以降最大 1.44 まで数\%ずつの割合で比較的幅広い分布が みられた（図 3).

\section{4. 顎関節症患者の症状別群の SCD}

患者群を症状別に分類した各群の SCD の平均は, 筋痛 群が 0.36 , 関節痛群 0.30 , 筋・関節痛群が 0.47 であっ た. 臨床上疼痛なしと判定された無痛群でも SCD が 0 で はなかった患者が 8 名（57\%）おり，SCDの平均は 0.08 を示した（図 4). 逆に, 臨床診査において, 疼痛を認め

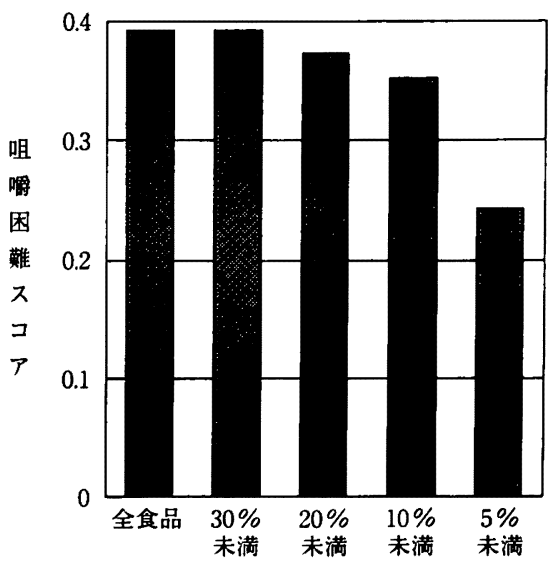

四 1 Score of chewing difficulties in the patients group

The left bar is the score for all foods. The other four bars are the scores of foods for which the percentages of invalid answers were less than $30,20,10$ and $5 \%$, respectively. Numbers of food items on each bar are 82, 78, 70,52 and 32 , respectively 無効回答率によりアンケートに用いる食品を選定 した場合の咀嚼困難スコア（対象：患者群） 全食品：82 食品 $30 \%$ 末満：無効回答率 $30 \%$ 以上の食品を除いた 78 食品, $20 \%$ 未満：同 $20 \%$ 以上を除いた 70 食 品, $10 \%$ 未満：同 $10 \%$ 以上を除いた 52 食品, $5 \%$ 未満：同 $5 \%$ 以上を除いた 32 食品

た群のなかにも SCD が0の者が筋痛群では 2 名（9\%）， 関節痛群では 6 名 $(46 \%)$, 筋・関節痛群では 1 名 $(8 \%)$ の合計 9 名が認められた。

\section{IV. 考 察}

1. 食品㧺取アンケートについて

咀嚼機能の評価については, 咀嚼能率を求める方 法 $^{17 ~ 25)}$, 咀嚼時の筋電図を解析する方法 ${ }^{1 \sim 3,26 ~ 28)}$, 咀嚼運 動経路を解析する方法4,29-31)，アンケートを用いて食品摄 取能を調査する方法 ${ }^{5 \sim 16)}$ などにより行われた報告がある. これらの方法には, それぞれ長所, 短所があるが, 本研究 においては，簡易に行えること，および患者の食生活を最 も反映しており，顎関節症の症状から生じる支障の程度を 具体的に把握できるという長所から，食品摄取アンケート を用いて咀嚼機能の評価を行う方法を選択した。この方法 の短所としては, 咀嚼時のだるさや疼痛を認識する閥值が 患者によりそれぞれ異なり，回答肢の選択基準も患者ごと に異なる可能性があることがあげられる。しかし，患者の 評価を主体に考えることは QOL の重要性が強調されてい る現在では，むしろ妥当な方法とも考えられる.

これまで, 食品摃取アンケートを用いて咀嚼機能の評価 


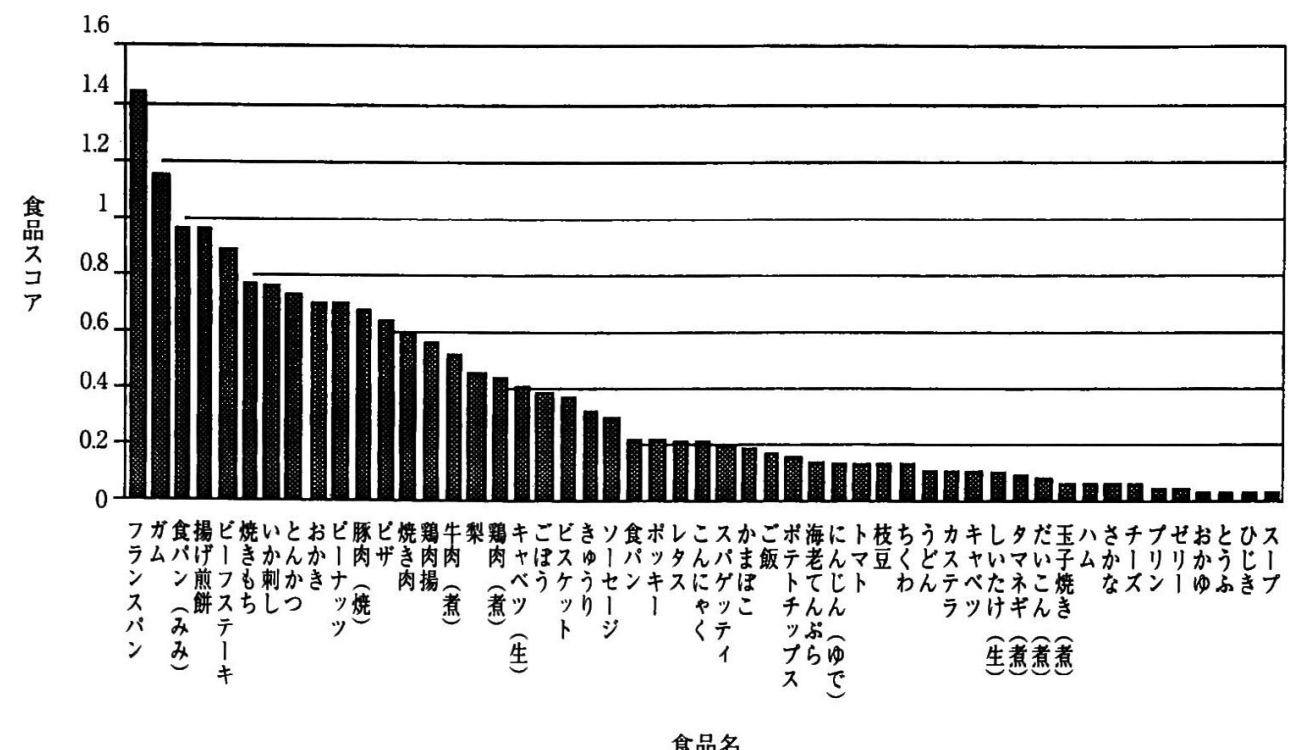

図 2 Scores of chewing difficulties in the patients group for each food 患者群の食品選定後の食品スコア

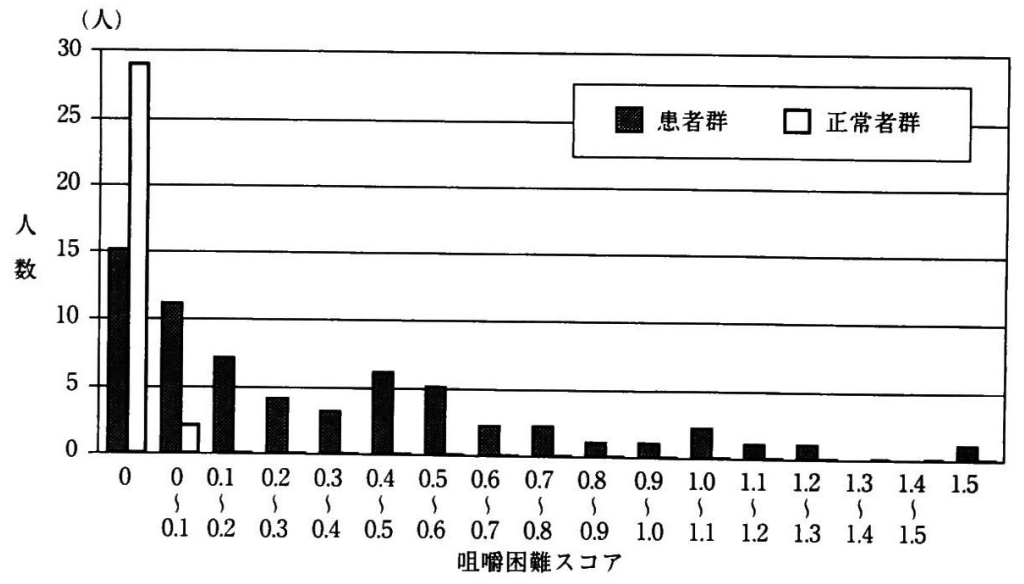

图 3 Distribution of scores of chewing difficulties in the normal subjects group and patients group 正常者群と患者群の咀橭困難スコアの分布

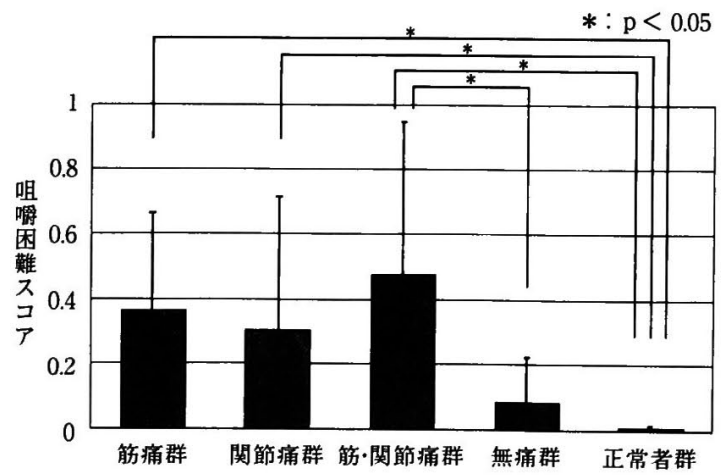

図 4 Scores of chewing difficulties by symptoms in the patients group 患者群の症状別咀咪困難スコア
を行った報告の対象は総義歯患者5,7 11,13,14)がほとんどで

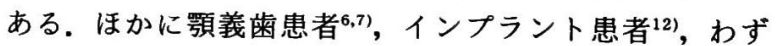
かではあるが顎関節機能障害患者を対象とした報告 ${ }^{15,16) も ~}$ あるが,これらで用いられてきたアンケートは, 総義㐘患 者へのアンケートをそのまま，あるいはわずかに改変した ものである. しかし, 過去の報告では食品の嗜好性の検討 が少ないこと,さらに総義歯患者と顎関節症患者では年齢 層の差から生じる食生活の違いが存在する可能性が高いこ とから, 本研究では, アンケートに用いる食品を再検討す ることとした. その結果, 無効回答率が高い, すなわち, 日常あまり食べられていない食品が多く存在することが明 らかになった. 無効回答率 $10 \%$ 以上のため削除した 30 食 品のなかには, なまこ, とり貝, らっきょう, クラゲ酢, 
するめ, マシュマロのほか, 過去の報告 ${ }^{5 \sim 16)} に$ 用いられて いる食品も多数含まれていた（表 3)．アンケートの結果 をスコア化する際に「嫌い・食べない」「わからない・知 らない」食品の割合が高くなるとスコアの信頼性は低くな る. 今回の結果から, アンケートに用いる食品の選定に は, 食品の嗜好性を検討することが重要であることが確認 された。

これまでのアンケートに用いられた食品数は, 山本 ${ }^{5}$ が 35 品目, 平井ら ${ }^{111}$ が 35 品目, 佐藤ら ${ }^{10)}$ が 20 品目, 榎本 $ら^{14)} 28$ 品目であり, われわれは 52 品目と多い. しか し, 無効回答率の低い食品であれば, 食品数が多いほど, より的確に個々の患者の食生活の支障度を把握することが できると思われる.アンケートの回答に要する時間は今回 の食品数でも数分であり, 臨床で用いる際にも問題になら ないと考えられる。

回答肢に関しては, 過去の報告のほとんどが,「普通に 食べられる」「工夫すれば食べられる」「食べられない」 「よくわからない」としている．頭関節症患者に対する咀 噹時痛の問診において,「痛くて食べられない」「咬んでる と顥がだるくなってくる」という訴えをよく経験すること から，これらの $2 つ は$ 同一の状態ではないと考え，今回は 分けた回答肢とすることにした. 回答肢のスコアの決め方 に関しては，食品の摄取難易度により食品別に重みをつけ る考え方もある ${ }^{11}$ が, 重み付けを行うとスコアの算定が非 常に複雑になるという考光狍もある. 今回のアンケート は, 日常の䅡関節症患者の診療において用いることを目標 としているため, 重み付けで計算がより複雑になることを 避け, 全食品共通で $0,1,2 ， 3$ の 4 段階のスコアとした. なお, 今回のようなアンケートを用いる場合には testretest などで信頼性の確認を行うのが望ましいが, 正常者

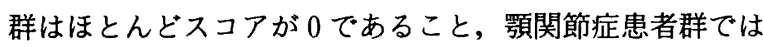
時間経過に伴い症状の変動がある可能性が高いことから， test-retest で信頼性の検討を行うのは困難であり, 今回は 行わなかった。今後，本アンケートに適した信頼性の確認 方法を検討する必要があると思われる。

\section{2. 顎関節症患者の咀哷機能について}

額関節症患者における食品スコアは高いものから順に, フランスパン, ガム, 食パン (みみ), 揚げせんべい, ビーフステーキ，たくあんなどであった．河野ら ${ }^{321}$ は，咀 嚼時痛を誘発する食品テクスチャーとしては, 硬さも関係 しているものの, 食品を飲み込める状態にまで砕くのに必 要な力を表現するガム性とも関連が深いと報告している が, 今回の結果はこれに一致するものである．また，食品

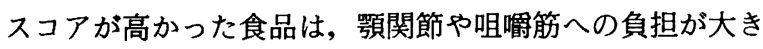
い食品と考えられることから，今回のデータは患者に顎関 節や咀畄筋の安静を指示する際, 制限すべき食品の説明を 行う上で非常に有用なものである.
顎関節症患者の咀嚼機能に関して栗田ら ${ }^{15,16)}$ は, 顎関節 機能障害患者の咀喵障害は高度で柔らかいものを除いたほ とんどの食品において認められること，また筋症状との関 連については言及していないものの, 関節疼痛の程度と咀 嚼スコアに相関関係があり, 症型別にはII 型, III型ロッ ク, IV型となるほど障害は重度であることを報告してい る. 本研究においても, 同様に多くの患者で咀嚼機能の障 害が認められた。また，患者群の SCD の分布は幅広く， 咀嚼機能の障害の程度は患者により大きく異なることが示 唆された，幅広い分布のなかには, 臨床所見で疼痛を認め

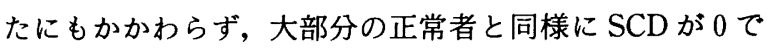
あった患者も 9 名みられた。顎関節症患者に認められる疼 痛の発現率について迫田ら ${ }^{33}$ は, 開口時痛が $58 \%$, 咀夁 時痛が $18 \%$, 許ら ${ }^{34)}$ は開口時痛が $65 \%$, 咀嚼時痛が 40 数\%, 家入ら ${ }^{35}$ は開口時痛が $32.6 \%$, 咀䱜時痛が $14.7 \%$ と報告しており, 開口時痛に比較して, 咀嚼時痛の発現頻 度は低いとされている。この理由の 1 つとして, 疼痛発現 時期が開口末期の場合, 開口時痛を有していても, 日常の 咀嚼運動に必要な開口量では, 開口時痛を引き起こすまで には至らないことが考えられる. 今回の SCD が0を示し た患者のなかにはそのような患者が多いものと考えてい る. 症状別に筋痛群と関節痛群の SCD を比較したとこ ろ, SCD の平均に有意な差は認められなかったものの, $\mathrm{SCD}$ が 0 の患者の割合は, 筋痛群では $9 \%$, 関節痛群で は $46 \%$ と大きな違いが認められた. 関節痛に関しては, 顎関節の滑膜炎とものを咬んだときの痛みに相関があると いう報告 ${ }^{36)}$ から, 滑膜炎の進行した症例では咀嚼時痛が発 現するものの, それ以外は開口時痛が主体となると思われ る.そのため, 今回の関節痛群にも咀嚼運動の開口量の範 囲内では障害を自覚しない患者が多く存在したものと考え られた. 一方, 筋痛群については, 大部分の症例で咀嚼機 能に支障が生じていることが明らかになった。これは，咀 嚼運動が開口相, 閉口相とも咀嚼筋群の活動なしには行え ないことを考えると，十分予想された結果ではあるが，患 者が満足して食生活を送れるためには, 筋症状のコント ロールは重要であることを示唆するものである.

また, 臨床上疼痛なしと判断された無痛群でも, SCD が 0 でなかった患者が 8 名（57\%）いたことは，今回のア ンケートが臨床所見より，より的確に患者の支障度を表し ている可能性を示すものと考えられた。 さらに，今回得ら れた患者全体の SCD は幅広く分布していたことから，顎 関節症患者の咀嚼機能の支障の有無を判別するだけでな く, 軽度のものから重度のものまで支障度をより細かく評 価するのにも適していると考えられた。すなわち, 個々の 患者の SCD を, 今回の全患者群の SCD の分布と比較す ることにより，その患者の食生活の支障度がどの程度であ るかを把握しやすくなるものと思われた。これらの点か ら, 今回の食品捸取アンケートによる SCD を用いた評価 
法は，顎関節症患者の咀嚼機能評価法として有用なものと 思われた。

\section{V. 結 論}

顎関節症患者の咀嚼機能について検討を行うため，顎関 節症患者 62 名, 正常者 31 名を対象として, 82 食品から なる食品摂取アンケートを行った。その結果，以下の結論 を得た。

1.「嫌い・食べない」「わからない・知らない」の選択 肢を選んだ被験者の割合（無効回答率）が高い食品の存在 が明らかになり，食品の赀好性を考慮に入れる必要性が示 唆された。そのため, 最終的にアンケートの対象食品とし て, 無効回答率 $10 \%$ 以上の食品を除外した 52 食品を選定 した.

2. 選択肢を支障の程度にあわせてスコア化（咀嚼困難 スコア, score of chewing difficulty；SCD）したところ, 患者群の筋痛群, 関節痛群, 筋・関節痛群ともに, 正常者 群より有意に大きな值を示した。しかし，患者群の SCD の分布は幅広く，なかには臨床所見での疼痛の有無と $\mathrm{SCD}$ による支障度の評価結果が一致しない患者も認めら れ，咀嚼機能の支障の程度は患者により大きく異なること が示された，したがって，顎関節症患者の治療において， 患者の症状が食生活に及ぼす影響をより細かく把握するた めには，今回の食品摂取アンケートによる SCD を用いた 咀嚼機能の評価法は有用であると思われた。

本論文の要旨は, 平成 10 年度日本補綴歯科学会東北・北海道支部 学術大会（平成 10 年 9 月 12 日, 郡山）において発表した。

\section{文献}

1）前田照太. 咬合性額関節症の筋電図学的研究. 歯科医学 43 ： 229-267, 1980

2) Möller E, Sheikholeslam A, Lous I. Response of elevator activity during mastication to treatment of functional dis orders. Scand J Dent Res $92: 64-83,1984$.

3）山口泰彦，内山洋一．筋電図咀嚼リスム（CV 值）を用いた顎 関節症患者の治療効果の判定法. 石岡 靖, 小林義典，長谷川 成男ほか編，頱口腔機能分析の基礎とその応用 380-389, 東京： デンタルダイヤモンド社, 1991

4）桑原俊也. 咀罚運動と顎関節異常の関連性に関する臨床的研 究. 阪大歯学誌 $34: 64-105,1989$

5）山本為之. 総義歯臼歯部人工歯の配列について（その2)一特に 反対咬合について一。補経臨床 $5: 395-400,1972$.

6）松浦正朗，野村隆祥，田中樹彦ほか。義顮装用者の簡単な咀絪

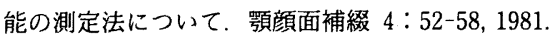

7）服部正巳，水野辰哉，石川 輔ほ力. 無歯顎頼補経の咀㑼機能 の回復について. 顎顔面補経 6:25-32, 1983.

8）細井紀雄，森戸光彦，椎名順朗ほか．全部床義歯患者の予後に
関する臨床的研究一装着 5 10 年の観察一第 1 報 アアンケート とリコール調査. 補緅誌 $30: 840-847,1986$.

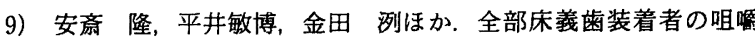
機能判定用食品についてーアンケート調査からの検討一. 補経 誌 $31: 1413-1420,1987$.

10）佐藤裕二，石田栄作，皆木省吾ほか，総義歯装着者の食品摂取 状況. 補緅誌 32：774-779, 1988.

11）平井敏博, 安斎 隆, 金田 洌ほか. 摄取可能食品アンケート を用いた全部床義菌装着者用咀嚼機能判定表の試作．補経誌 $32: 1261-1267,1988$

12）上田 実，沢木桂弘，江幡晃治ほか．Osseointegrated implant (Brånemark System) を用いて咬合再建を行った 5 例一咀覆能 力の変化を中心に一。 日口外誌 $36: 704-711,1990$.

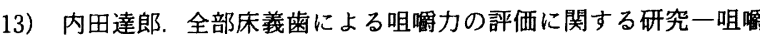
能力に影響する因子と評価に適した食品の検討一， 口病誌 58 ： 182-197, 1991.

14）榎本友彦, 塙 浩昭, 荒井節男ほか. アンケート調査による有 床義歯装着者の咀嚼機能評価食品の検討．補緅誌 $35 ： 1168-$ $1176,1991$.

15）栗田 浩，倉科憲治，小木曾 暁ほか．䫇関節機能障害患者の 咀罚機能一第 1 報 食品摄取状況から見た評価一。 日頻誌 5 ： 10-17, 1993.

16）栗田 浩，倉科憲治，小木曾 暁ほか. 顎関節機能障害患者の

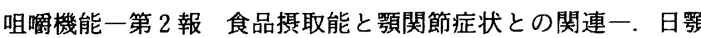
誌 $5: 18-27,1993$

17) Manly RS, Bramley LC. Masticatory performance and efficiency. J Dent Res 29:462-488, 1950.

18）石原寿郎. 篩分法による咀罾能率の研究. 口病誌 $22: 207-255$, 1955.

19）羽田 勝. 咀噮能力に影響を及ほす諸因子とそれらの関係の統 計学的解析. 広大歯誌 $10: 21-33,1978$.

20) Helkimo E, Carlsson GE, Helkimo M. Chewing efficiency and state of dentition. Acta Odontol Scand $36: 33-41,1978$.

21) Gunne HSJ. Masticatory efficiency. A new method for determination of the breakdown of masticated test material. Acta Odontol Scand 41:271-276, 1983.

22) Shi CS, Ouyang G, Guo TW. Masticatory efficiency deter mined with direct measurement of food particles masticated by subjects with natural dentitions. J Prosthet Dent $64: 723-$ $726,1990$.

23）古谷暢子，吉田 実，野首孝祠ほか、試験用グミゼリーを用い た咀絪機能評価一有歯秪者における年齢差について一，補緅誌 $38: 89-97,1994$

24）田中 彰、志賀 博，小林義典ほか。グミゼリ一咀礵時のグル コースの溶出量の分析による運動機能および咀㑼筋筋活動の定 量的評価. 補緅誌 38 :1281-1294, 1994.

25）沖山誠司，吉田 実，山本 誠ほか。試験用グミゼリーの物性 と咬合接触状態が咀嚼能率に及浑す影響。補緅誌 $40: 710-717$ 1996.

26）長沢 亨，佐々木 元，棟久信宏ほか，咬筋および側頭筋活動 と咀嚼能率との関係に関する実験的研究。補経誌 $18: 319-322$ 1975.

27）津留宏道，広田賢徳，丸山剛郎ほか，各種食品咀摆時における 
咀哷筋活動の筋電図学的研究. 補綴誌 $79: 162-172,1979$.

28）津留宏道，岡根秀明．咀哷筋筋電図による咀噯機能の判定. QE $1: 44-58,1982$

29）瑞森简弘，桑原隆男，西尾公一ほか，咀鲋運動に関する臨床的 研究一食品の大きさ・固さの影䈏について一, 補綴誌 29 ： 1062-1069, 1985.

30）志賀 博，小林義典. 咀婙運動の分析による咀罍機能の客観的 評価に関する研究．補緅誌 $34: 1112-1126,1990$.

31）志賀 博，小林義典，中島邦久ほか. 食品の大きさが咀嚼運動 に及ほす影響一下䫑運動と咀撂筋筋活動一. 䫑機能誌 $1: 249$ $260,1995$.

32）河野 亘，田中昌博，徳永 徹ほか，䫑機能異常者において咀 筁時痛を誘発する食品テクスチャー。補綴誌 $34: 873-877$, 1990.

33）迫田隅男，芝 良祐，真鍋敏彦ほか、䫑関節症の臨床統計的観 察 過去 10 年間の臨床統計と予後調査. 日額誌 $2: 79-88,1990$
34）許 重人，渡辺 誠，佐々木啓一ほか. 頭関節症の臨床像に関 する研究. 補緅誌 $36: 783-790,1992$.

35）家入美香，冲本公繪，家入浩二ほか．類関節症の臨床統計的観 察. 補緅誌 32 : 1024-1032, 1988.

36）村上賢一郎，瀬上夏樹，森家祥行ほか。頜関節内クロースドロ ック症例における関節鏡所見と関節疼痛の関連痛について．日 口外誌 $37: 456-462,1991$

著者連絡先：嶋谷 庸子

厂060-8586 北海道札幌市北区北 13 条 西 7 丁目

TEL : 011-706-4275

FAX : 011-706-4276 